\title{
Pengawasan Pemerintahan oleh Dewan Perwakilan Rakyat Daerah Tidak Bertentangan dengan Kedudukan Hukum Kepala Daerah sebagai Anggota Partai Politik
}

\author{
Government oversight by the Regional House of Representatives is not \\ contrary to the Legal Status of the Regional Head as Member of the Political \\ Party
}

\author{
Rusmayadi \\ Advokad Bakti Keadilan \\ E-mail: Rusmayadilafran@yahoo.com \\ Muh. Sabaruddin Sinapoy \\ Pascasarjana Universitas Halu Oleo \\ E-mail: sabaruddinsinapoy@yahoo.com \\ Kamaruddin Jafar \\ Pascasarjana Universitas Halu Oleo \\ E-mail: Kamaruddinjafar88@gmail.com
}

\begin{abstract}
This paper is aimed at identifying government oversight by the DPRD which does not conflict with the legal position of the regional head as a member of a political party as in the understanding that our country is a democratic country in which the DPRD controls the administrators of regional government.

The position of regional head as a member of a political party focuses on the supervision of the DPRD Through this legislative body, it can be seen that the function of the DPRD is a public control tool for local governments in terms of transparency, participation, accountability, democracy and justice.

This study uses a normative approach, namely the existence of theories and concepts that are put forward by the opinions of experts and legislation. based on the theory of political trias which was proposed by John Locke (1632-1704), and philosopher Monstequieu in 1748.

The results of this study, based on the growing issue that there are several regions where regional heads still use their progressive rights based on political party policies to become the organization's place. So that all decisions are based on the assumptions of the supporting party on current government policies. As in Konawe district, the head of the area in the PAN party, Konawe Selatan Regency was stretched from the GOLKAR party and Bombana district was stretched by the PAN Party, each of which had the right to determine the Chairperson of the DPRD from the same party.
\end{abstract}


Thus it can be concluded that the function of government oversight by the DPRD does not conflict with the legal position of the regional head as a member of a political party because in this case the DPRD is a media control society in overseeing the wheels of regional head governance towards good governance.

Keyword: District head; DPRD Supervision Function; Political parties

\begin{abstract}
Abstrak: Tulisan ini ditujukan untuk mengidentifikasi Pengawasan pemerintahan oleh DPRD tidak bertentangan dengan kedudukan hukum kepala daerah sebagai anggota partai politik sebagaimana dalam paham negara kita adalah negara demokrasi yang mana peranan masyarakat dalam hal ini DPRD melakukan kontrol terhadap penyelenggara pemerintahan daerah.

Kedudukan kepala daerah sebagai anggota partai politik dengan menitik beratkan pada pengawasan DPRD Melalui lembaga legislatif inilah dapat di lihat pelaksanaan fungsi DPRD sebagai alat kontrol masyarakat terhadap pemerintah daerah baik secara transparansi, partisipasi, akuntabilitas, demokrasi dan berkeadilan.

Penelitian ini menggunakan metode pendekatan normatif yakni adanya teori dan konsep yang di kemukakan oleh pendapat para ahli dan perundang-undangan. berdasarkan teori yakni trias politika yang di kemukakan oleh John Locke (16321704), dan ahli filsuf Monstequieu pada tahun 1748.

Adapun hasil dari penelitian ini, berdasarkan isu yang berkembang bahwa ada beberapa daerah yang kepala daerah yang masih menggunakan hak progresifnya berdasarkan kebijakan partai politik menjadi wadah organisasinya. Sehingga segala keputusan berdasarkan asumsi-asumsi dari pada partai pendukung atas kebijakan pemerintah saat ini. Seperti di kabupaten Konawe kepala daerah di usung dari partai PAN, Kabupaten Konawe Selatan di usung dari partai GOLKAR dan kabupaten Bombana di usung oleh Partai PAN yang mana masing-masing dari kepala daerah memiliki hak untuk menentukan Kedudukan Ketua DPRD dari partai yang sama.

Dengan demikian dapat disimpulkan bahwa fungsi pengawasan pemerintahan oleh DPRD tidak bertentangan dengan kedudukan hukum kepala daerah sebagai anggota partai politik karena dalam hal ini DPRD sebagai media kontrol masyarakat dalam mengawasi roda pemerintahan kepala daerah menuju pemerintahan yang baik.
\end{abstract}

Kata kunci: Kepala Daerah; Fungsi Pengawasan DPRD; Partai Politik

\title{
PENDAHULUAN
}

Negara Kesatuan Republik Indonesia (NKRI) ialah negara kesatuan yang didesentralisasikan, artinya di sini negara Indonesia terdiri dari daerah-daerah, bukan terdiri dari negara bagian, sehingga tidak ada negara dalam negara. Dalam Pasal 18 ayat (1) dinyatakan "Negara Kesatuan Republik Indonesia dibagi atas daerah-daerah provinsi, dan daerah provinsi itu dibagi atas kabupaten dan kota, yang tiap-tiap provinsi, kabupaten dan kota itu mempunyai pemerintahan daerah yang diatur dengan Undang-undang". Kemudian pemerintahan daerah mengatur dan mengurus sendiri urusan pemerintahan menurut asas otonomi. Dalam mengatur dan mengurus sendiri urusan rumah tangga daerah, setiap daerah mempunyai kepala daerahnya masing-masing.

Dewan Perwakilan Rakyat Daerah atau DPRD merupakan lembaga perwakilan rakyat daerah dan berkedudukan sebagai unsur penyelenggaraan pemerintahan daerah. 
DPRD memiliki fungsi pengawasan, yaitu pengawasan terhadap Peraturan Daerah (PERDA), Anggaran Pendapatan Belanja Daerah (APBD), kebijakan pemerintah daerah dalam melaksanakan program pembangunan daerah dan kerja sama Internasional di daerah dalam rangka menuju tata kelola pemerintahan yang baik (good governance) dalam pelaksanaannya belum terlaksana dengan baik.

Tujuan penelitian ini adalah untuk mengetahui kewenangan DPRD dan kendala yang dihadapi dalam melaksanakan fungsi pengawasan menuju tata kelola pemerintahan yang baik (good governance). Penelitian ini bertitik tolak dari berbagai peraturan perundang-undangan sebagai norma hukum positif yang menjadi dasar serta fakta yang di dapat dalam setiap pengawasan DPRD sehingga fungsi pengawasan yang merupakan kewenangan DPRD tidak sejalan dengan peraturan perundang-undangan yang berlaku, hal di sebabkan kepentingan DPRD berbeda-beda dan dapat menyebabkan sulitnya pengawasan di laksanakan secara baik.

Tugas dan wewenang dari kepala daerah antara lain. ${ }^{1}$ a. Memimpin penyelenggaraan pemerintahan daerah berdasarkan kebijakan yang di tetapkan bersama Dewan Perwakilan Rakyat Daerah (DPRD), b. Mengajukan rancangan peraturan daerah, c. Menetapkan peraturan daerah yang telah mendapat persetujuan bersama DPRD, $d$. Menyusun dan mengajukan rancangan Peraturan Daerah tentang Anggaran Pendapatan Belanja daerah (APBD), kepada DPRD untuk dibahas dan ditetapkan bersama, e. Mengupayakan terlaksananya kewajiban daerah, f. Mewakili daerahnya di dalam dan di luar pengadilan, dan dapat menunjuk kuasa hukum untuk mewakilinya sesuai dengan peraturan perundang-undangan serta g. Melaksanakan tugas dan wewenang lain sesuai dengan peraturan perundang-undangan.

Namun hal ini fungsi pengawasan DPRD terhadap kepala daerah tidak akan berjalan dengan baik ketika kepala daerah yang masih menjadi anggota partai politik bahkan menjabat sebagai ketua partai politik, sehingga DPRD akan mengalami kendala dan kesulitan dalam melakukan fungsi pengawasan terhadap kepala daerah yang masih menjadi anggota partai politik.

Berdasarkan uraian tersebut di atas maka peran kepala daerah yang berasal dari dukungan partai politik sangat penting dalam penyelenggaraan pemerintahan daerah,

1 Pasal 25 Undang-Undang Republik Indonesia Nomor 32 Tahun 2004 tentang Pemerintah daerah (Lembaran Negara Republik Indonesia Tahun 2004 Nomor 125, Tambahan Lembaran Negara Republik Indonesia Nomor 4437). 
mengingat dalam konteks saat ini kepala daerah yang berasal dari anggota partai politik akan sulit dilakukan pengawasan oleh DPRD hal ini disebabkan, kepala daerah serta anggota DPRD ada yang berasal dari Partai politik yang sama sehingga fungsi pengawasan DPRD terhadap kinerja kepala daerah tidak akan berjalan sebagaimana tanggung jawab DPRD dalam melakukan fungsi pengawasannya terhadap kepala daerah.

\section{METODE PENELITIAN}

Berdasarkan Penelitian yang di lakukan oleh peneliti, dengan menganalisis fungsi pengawasan pemerintahan oleh DPRD dalam kedudukan hukum kepala daerah sebagai anggota partai politik. Secara ilmiah dapat memberikan suatu gambaran tentang Kedudukan Hukum Kepala Daerah Sebagai Anggota Partai Politik sebagai satu kesatuan dari Sistem Pemerintahan Daerah Kabupaten. Di samping itu juga dapat memberikan gambaran yang seutuhnya tentang kenyataan pelaksanaan Fungsi Pengawasan Pemerintahan Daerah Kabupaten oleh DPRD. Sehingga Penelitian ini berdasarkan metode penelitian normatif yaitu teori dan konsep kedaulatan rakyat, pemerintahan, partai politik dan kedudukan hukum serta Perundang-undangan berdasarkan ketentuan yang berlaku. Jenis dan sumber bahan hukum yang digunakan untuk mengkaji, meneliti dan menganalisis penelitian ini yakni bahan hukum primer, sekunder.

\section{ANALISIS DAN PEMBAHASAN}

\section{Fungsi Pengawasan Pemerintahan oleh Dewan Perwakilan Rakyat Daerah}

Dalam paham negara hukum demokrasi peranan masyarakat untuk melakukan pengendalian terhadap penyelenggara pemerintahan menjadi penting dalam rangka civil society. Lembaga legislatif dalam pandangan negara hukum demokrasi adalah lembaga pembuat Undang-Undang sekaligus melekat fungsi pengawasan dalam rangka check and balances. Kalau legislatif kuat dalam pelaksanaan fungsinya sebagai pembuat UndangUndang (UU) dan pelaksanaan fungsi pengawasan dapat melahirkan pemerintahan yang kuat dan efektif. Sebaliknya, kalau legislatif lemah akan melahirkan pemerintahan yang amburadul dan manajemen pemerintahan menjadi rusak, Unsur-unsur penting dalam penataan pemerintahan, termasuk penataan pengawasan pemerintahan maka negara menuju tata kelola pemerintahan yang baik (good governance), yakni taat pada hukum, 
transparansi, partisipasi, akuntabilitas, demokrasi, dan keadilan hanya menjadi slogan belaka, alhasil dapat melahirkan pemerintahan Abunawas ${ }^{2}$.

Fungsi pengawasan yang sedemikian besar yang dimiliki oleh legislatif mulai dari perencanaan, pelaksanaan, pengawasan, dan pertanggungjawaban, kalau dilaksanakan secara maksimal dan tidak disalahgunakan akan melahirkan tata kelola pemerintahan yang baik, tidak akan terjadi pembobolan sehingga dapat merugikan daerah atau negara. Mandeknya fungsi pengawasan oleh Dewan Perwakilan Rakyat Daerah (DPRD) misalnya disebabkan karena lembaga legislatif yang sejatinya melaksanakan fungsinya dalam hal pengawasan telah ikut konspirasi persekongkolan yang dimana Kepala Daerahnya berasal dari partai koalisi yang besar dilembaga legislatif. Salah satu aspek penting dari fungsi DPRD menurut Undang-Undang No. 32 Tahun 2004 Tentang Pemerintahan Daerah dan Undang-Undang No. 27 Tahun 2009 Tentang MPR, DPR, DPD, dan DPRD adalah fungsi pengawasan (legilative control). Dari berbagai referensi dan teori yang melahirkan negara dan pemerintahan, seperti doktrin trias politik yang membagi kekuasaan menjadi tiga bagian sangat berpengaruh terhadap pelaksanaan pemerintahan di berbagai negara.

Doktrin trias politika dipahami sebagai suatu prinsip normatif yang menyatakan bahwa kekuasaan sebaiknya tidak diserahkan kepada orang yang sama untuk mencegah penyalahgunaan oleh pihak yang berkuasa, dengan demikian, diharapkan pelaksanaan demokrasi dan hak-hak asasi warga negara lebih terjamin. Untuk pertama kalinya doktrin ini dikemukakan oleh John Locke (1632-1704) dan Monstiquieu (1689-1755), doktrin ini biasanya ditafsirkan sebagai pemisahan kekuasaan (separation of pawer). Filsuf Inggris, John Locke, mengemukakan konsep ini dalam bukunya Two Treaties on Civil Goverment (1690) yang ditulisnya sebagai kritik atas kekuasaan absolut dari raja-raja Stuart serta membenarkan Revolusi Gemilang (The Glorious Revolution) tahun 1688 yang dimenangkan oleh parlemen Inggris menurut, John Locke kekuasaan negara dibagi dalam tiga kekuasaan yaitu, kekuasaan Legislatif, kekuasaan Eksekutif, dan kekuasaan Federatif, masing-masing kekuasaan ini terpisah-pisah satu sama lain.

Kekuasaan legislatif menurut Monstequieu adalah kekuasaan membuat UndangUndang, kemerdekaan hanya dapat dijamin jika ada pemisahan fungsi pemerintah tidak dipegang oleh satu orang atau badan, tetapi oleh tiga orang atau badan terpisah. Menurut Monstequieu kalau kekuasaan legislatif dan kekuasaan eksekutif disatukan dalam satu

${ }^{2}$ Hendra Karianga. Politik Hukum Dalam Pengelolaan Keuangan Negara. Jakarta: Prenadamedia Group, 2013. hlm. 311. 
orang atau dalam satu badan penguasa, maka tak akan ada kemerdekaan. Pemisahan kekuasaan dalam rangka menjamin terselenggaranya kemerdekaan individu, dalam kerangka itulah diperlukan fungsi pengawasan legislatif terhadap jalannya pemerintahan.

Strategi dan perencanaan pembangunan di Indonesia oleh Konstitusi kita (Negara Indonesia), telah membuka peluang yang sangat besar dan strategis untuk pencapaian tujuan Negara Republik Indonesia. Karena itu daerah yang paling sentral dijadikan pembangunan berbasis otonom adalah kabupaten dan kota (di setiap provinsi) dalam hal ini titik fokus pada efektivitas pengawasan DPRD kabupaten dan kota dalam pembangunan daerah. Hal ini sangat penting karena keberadaan DPRD dalam mengimplementasikan fungsi pengawasan sangat menentukan keberhasilan kepala daerah dan jajarannya dalam melaksanakan tugas pembangunan di daerah yang dilandasi oleh asas-asas pemerintahan yang baik.

Salah satu fungsi DPRD yang sentral menjadi perhatian dan pembicaraan semua kalangan adalah fungsi pengawasan. Dalam hukum administrasi negara fungsi pengawasan mengandung tindakan lembaga yang bersifat preventif dan preventif yang mengandung makna mengevaluasi dan mengawasi program-program pemerintah daerah. Oleh karena mengandung makna mengevaluasi, konsekuensinya adalah semua kebijakan pemerintah daerah dalam menjalankan program-programnya tidak serta merta dimentahkan oleh karena sebuah pengawasan.

\section{Kedudukan Hukum Kepala Daerah}

Termasuk dalam penyelenggaraan pemilihan kepala daerah. Secara riil, keberhasilan dalam melaksanakan pemilihan kepala daerah secara langsung itu adalah sebagai arus besar dalam pemikiran dan kehendak yang berkembang di setiap momen pemilihan kepala daerah (Pilkada) secara langsung untuk memperoleh sosok yang benar-benar sesuai dengan harapan masyarakat setempat. Dan hal ini seharusnya kedudukan calon kepala daerah ketika sudah terpilih secara demokratis lewat usungan partai politik atau koalisi beberapa partai politik dan menjadi kepala daerah, sudah seharusnya melepas atribut kepartaian atau keanggotaannya sebagai bagian dari partai politik tersebut.

Pada tataran konseptual, pencermatan atas perjalanan pemilihan kepala daerah ini sebenarnya muncul atas dasar tarik ulur kewenangan pemerintah pusat dengan pemerintah daerah dalam Negara Kesatuan Republik Indonesia. Namun di sepanjang sejarah hukum administrasi pemerintahan, mengedepannya pemilihan kepala daerah 
secara langsung ini baru dapat direalisasikan setelah reformasi pasca krisis multidimensi, termasuk atas pemerintahan negara tahun 1998. Masa ini seolah menjadi kran kebebasan bagi ekspresi masyarakat di semua bidang kehidupan. ${ }^{3}$

Jauh sebelum itu, pemilihan secara langsung atas kepemimpinan formal pada ranah publik hanya sampai pada batas pemimpin lokal tingkat desa. Bahkan pemilihan kepala desa di pulau Jawa sudah dilakukan semenjak penjajahan Belanda atau jauh sebelum itu dengan konsekuensi dipilihnya seorang kepala desa yang mempunyai akses kekuasaan atas rakyatnya. Akses kekuasaan di desa biasanya senantiasa berkorelasi dengan kekuatan ekonomi, kekuatan otot dan kepiawaian mengelola sumber-sumber perbedaan yang ada di masyarakat desa.

Budaya lokal di berbagai daerah di Indonesia jenisnya beragam itu, ketika bersentuhan dengan sistem demokrasi kemudian melahirkan dua pandangan yang berbeda. Pertama, budaya politik demokratis tidak memiliki akar dalam budaya lokal masyarakat. Kedua, nilai-nilai demokrasi dengan berbagai variannya telah tumbuh sejak lama di Indonesia seiring dengan dinamika budaya lokal masyarakat. ${ }^{4}$

Setelah Indonesia merdeka, posisi pemerintahan daerah lebih mengemuka sebagai bagian dari pelaksanaan otonomi yang mengedepankan dominasi pemerintah pusat. Pemerintah daerah lebih mengedepankan sebagai pelaksana dari berbagai kebijakan pusat. Dalam hubungan ini, tarik ulur di dalam permasalahan yang berkisar pada otonomi daerah pada satu sisi dan negara kesatuan pada sisi lain sudah berlangsung lama. Tepatnya semenjak kemerdekaan Indonesia yang secara formal memastikan bentuk negara kesatuan. Baik permasalahan yang berkisar pada otonomi daerah maupun negara kesatuan itu sama-sama mempergunakan referensi demokrasi sebagai satu ukuran untuk menyebut bahwa keduanya berada dalam satu bingkai demokrasi.

Di dalam negara kesatuan Republik Indonesia, demokrasi yang dimaksudkan itu adalah demokrasi Pancasila. Sebutannya mudah dijelaskan tetapi ketika diurai, mengandung semacam ajaran yang abstrak dan dari operasional. Bahkan operasionalisasinya senantiasa dinilai tidak terlepas dari politik kepentingan, khususnya oleh penguasa. Oleh karena itu, di dalam perkembangan berikutnya baik para pejabat,

3 Samsul Wahidin. Hukum Pemerintahan Daerah, "Mengawasi Pemilihan Umum Kepala Daerah". Yogyakarta: Pustaka Pelajar, 2008, hlm. 62.

4 Siti Zuhro dkk. Demokrasi Lokal Perubahan dan Kesinambungan. Yogyakarta: Ombak,. 2009. hlm. 2 
apalagi warga masyarakat mulai ragu untuk menyebut bahwa demokrasi di Indonesia ini adalah demokrasi Pancasila, apalagi analisis lebih lanjut dari itu semakin sayup dan jauh.

Dengan demikian sistem pemerintahan daerah di Indonesia, unsur pemerintah daerah merupakan salah satu bagian dari unsur pemerintahan daerah. Selanjutnya unsur pemerintah daerah juga terdiri dari 2 (dua) unsur yakni, unsur kepala daerah dan unsur perangkat daerah. Kepala daerah merupakan unsur yang mengepalai suatu daerah otonom dan juga memimpin pelaksanaan pemerintah daerah dan sekaligus juga sebagai penanggung jawab terhadap proses penyelenggaraan pemerintahan daerah. Kepala daerah, sampai saat ini dipilih secara demokratis, baik melalui usungan partai politik maupun lewat pencalonan independen, pemilihan tersebut dilakukan atau dilaksanakan secara langsung oleh masyarakat daerah yang memenuhi syarat sebagai pemilih.

Jauh sebelum itu, pemilihan secara langsung atas kepemimpinan formal pada ranah publik hanya sampai pada batas pemimpin lokal tingkat desa. Bahkan pemilihan kepala desa di pulau Jawa sudah dilakukan semenjak penjajahan Belanda atau jauh sebelum itu dengan konsekuensi dipilihnya seorang kepala desa yang mempunyai akses kekuasaan atas rakyatnya. Setelah Indonesia merdeka, posisi pemerintahan daerah lebih mengemuka sebagai bagian dari pelaksanaan otonomi yang mengedepankan dominasi pemerintah pusat. Pemerintah daerah lebih mengedepankan sebagai pelaksana dari berbagai kebijakan pusat. Dalam hubungan ini, tarik ulur di dalam permasalahan yang berkisar pada otonomi daerah pada satu sisi dan negara kesatuan pada sisi lain sudah berlangsung lama. Tepatnya semenjak kemerdekaan Indonesia yang secara formal memastikan bentuk negara kesatuan. Baik permasalahan yang berkisar pada otonomi daerah maupun negara kesatuan itu sama-sama mempergunakan referensi demokrasi sebagai satu ukuran untuk menyebut bahwa keduanya berada dalam satu bingkai demokrasi.

Kepala daerah di Indonesia terdiri dari Gubernur sebagai Kepala Daerah Provinsi, Bupati sebagai Kepala Daerah Kabupaten, dan Walikota Sebagai Kepala Daerah Kota. Dalam menyelenggarakan urusan pemerintahan daerah, kepala daerah memiliki tugas, fungsi, kewenangan dan kewajiban yang telah diatur dalam peraturan perundangundangan. Tugas, fungsi, kewenangan dan kewajiban seorang kepala daerah senantiasa berubah-ubah antara satu Undang-Undang (UU) dengan Undang-Undang lainnya tentang 
pemerintahan daerah, dan sangat tergantung pada dinamika masyarakat daerah dan tuntutan dari dinamika pemerintahan daerah itu sendiri. ${ }^{5}$

Terkait dengan persoalan dalam penyelenggaraan pemerintahan daerah sangat erat hubungannya dengan pemberian dan pelimpahan kewenangan antara unsur pemerintah pusat terhadap pemerintah daerah, karena kewenangan yang dijalankan oleh pemerintah daerah tidak lain adalah wujud dari pendistribusian kekuasaan eksekutif, dari Presiden kepada pemerintah daerah.

\section{Pelaksanaan Fungsi Pengawasan Pemerintahan oleh DPRD dalam Kedudukan Hukum Kepala Daerah sebagai Anggota Partai Politik}

Daerah sebagai panggung politik telah menjadi arena atau drama politik bagi masyarakat lokal, terutama dari para elitenya. Pada era sekarang ini, peristiwa Pemilihan Umum Kepala Daerah (Pemilukada) tak kurang menariknya dengan pemilu nasional. Bahkan dalam hal-hal tertentu, peristiwa Pemilukada tampak lebih sensitif dan menarik untuk dikaji dari pemilu nasional. Ketika diterapkan pemilihan langsung di berbagai daerah hampir setiap pesta demokrasi di daerah selalu diwarnai konflik, ketegangan, dan berbagai dinamika politik yang lebih keras dan tajam.

Kebijakan desentralisasi kekuasaan yang kini telah berlangsung kemudian berjalan semakin menarik ketika bersentuhan dengan budaya-budaya lokal di berbagai daerah di Indonesia yang jenisnya sangat plural. Langgam dan budaya di daerah bukan sekedar menjadi ornamen, melainkan justru menjadi penentu bagi berlangsungnya dramatika politik lokal, termasuk praktik demokrasi di daerah.

Di level legislatif, fenomena serupa tak kalah mengerikannya, banyak anggota Dewan Perwakilan Rakyat Daerah (DPRD) di daerah yang tidak mempunyai pengetahuan, pengalaman, dan kecakapan yang memadai dalam menjalankan proses pengawasan dan legislasi. Kurangnya kepedulian ataupun respons para wakil rakyat dalam menjalankan tugas pengawasan menimbulkan dampak negatif dalam penyelenggaraan pemerintahan daerah, hal ini disebabkan kepala daerah dan wakil rakyat berasal dari partai yang sama sehingga proses pengawasan tidak berjalan sesuai dengan harapan rakyat. Salah satu contohnya adalah kurangnya perhatian dan respons wakil rakyat terhadap aspirasi warga. Produk Undang-Undang daerah kerap kali cenderung menindas kepentingan rakyat yang

5 Rahyunir Rauf. Asas Penyelenggaraan Pemerintah Daerah. Yogyakarta: Nusamedia, 2018. hlm. 36 
memilihnya. Banyak fakta dan anekdot terkait keterbatasan kemampuan wakil rakyat berkembang pesat dalam lingkungan masyarakat. ${ }^{6}$

Dapat di lihat Fenomena politik dinasti yang sekarang ini muncul utamanya seiring dengan terkuaknya praktik politik di Provinsi Banten. Bahwa Provinsi Banten sebelumnya telah dikuasai oleh keluarga Ratu Atut Chosiyah. Atut Chosiyah adalah Gubernur Banten sejak 2007-2017, dan politik dinasti telah menggurita dalam struktur politik Banten. Posisi-posisi penting dan strategis banyak dipegang oleh keluarga besar Atut Chosiyah.

Salah satu imbas dari kebijakan desentralisasi dan otonomi daerah adalah menjamurnya dinasti dan oligarki politik dai daerah. Apa yang terjadi di era otonomi daerah dan desentralisasi ini bukanlah desentralisasi dalam arti yang sesungguhnya. Melainkan sebaliknya fenomena ini di era otonomi dan desentralisasi ini justru ditandai dengan menguatnya arus oligarki dan dinasti politik, baik yang terjadi dalam konteks kedaerahan juga melibatkan institusi partai politik. Dalam konteks daerah, oligarki politik terjadi dengan munculnya dinasti politik yang memunculkan raja-raja kecil di daerah. Sementara di partai politik ditunjukkan dengan kuatnya arus sentralisasi kebijakan partai politik. Sekarang ini, kebijakan adapun dalam sebuah partai politik selalu ditentukan dari pusat. Termasuk para anggota dewan di parlemen yang berasal dari beragam partai politik harus mengikuti kebijakan yang telah digariskan oleh pimpinan pusat partai.

Otoritas pimpinan pusat partai politik atau minimal dewan pimpinan pusat sebuah partai terlihat sangat dominan. Apalagi soal pimpinan kepala daerah, penentunya tidak lain adalah pimpinan pusat. Kader yang hendak diturunkan menjadi pimpinan daerah dari sebuah partai politik, selalu ditentukan dari pimpinan pusat parpol. Akhirnya otoritas pusat partai yang terlalu dominan itu sering kali bertentangan dengan aspirasi warga atau konstituen partai di daerah. Inilah paradoks otonomi daerah dan desentralisasi kekuasaan. Apa yang terjadi, justru dinasti politik dan sentralisasi kekuasaan dan wajahnya yang baru. $^{7}$

Dinasti dan oligarki politik, secara sektoral dan struktural, bukan hanya terjadi di sekitar partai politik saja tetapi juga disektor pemerintahan. Hal ini kemudian membawa ambiguitas dan absurditas eksistensi parpol sebagai pilar demokrasi. Munculnya dinasti dan oligarki partai politik itu, kemudian mengubah fungsi utama parpol.

\footnotetext{
6 Abd. Halim. Politik Lokal, Aktor, Problem, dan Konflik Dalam Arus Demokratisasi. Malang Jatim: Intrans Publishing, 2018. hlm. 118

7 Ibid hlm. 145.
} 
Sehubungan dengan hak tersebut dengan adanya sistem pemilihan kepala daerah secara langsung dan di usung oleh partai politik atau koalisi beberapa partai politik dapat meningkatkan legitimasi politiknya dalam memimpin penyelenggaraan pemerintahan daerah, sekaligus menciptakan (checks and balances) dalam hubungannya dengan DPRD. Namun apabila DPRD terlalu lemah atau dikuasai oleh partai politik yang sama dengan kepala daerah akan menciptakan (power shift) ke arah (executive heavy). Oleh karena itu pemberdayaan DPRD dalam hal pengawasan bersama masyarakat sangat penting untuk menciptakan keseimbangan antara eksekutif daerah dengan DPRD. ${ }^{8}$

Pemahaman antara eksekutif daerah dan DPRD terhadap rencana strategi daerah, baik jangka panjang maupun menengah, memberikan kesamaan persepsi mengenai bagaimana seharusnya kinerja pemerintah daerah dalam menyediakan pelayanan terhadap warganya, kesamaan persepsi ini sangat penting menciptakan kesamaan pemikiran dan arah kegiatan eksekutif daerah dan DPRD.

Pola hubungan kepala daerah dengan DPRD tergantung paradigma yang digunakan pada peraturan perundang-undangan, yang mengatur pemerintahan daerah. Dalam peraturan perundang-undangan tersebut mengatur mengenai pertanyaan filosofis sebagai berikut, Siapa, mengerjakan apa, bagaimana caranya. Pertanyaan siapa berkaitan erat dengan kedudukan masing-masing, baik unsur kepala daerah maupun unsur DPRD dalam sistem pemerintahan daerah. Pertanyaan mengerjakan apa berkaitan erat dengan tugas pokok dan fungsi lembaga masing-masing. Sedangkan pertanyaan bagaimana caranya, berkaitan erat dengan mekanisme dan prosedur kerja sesuai kedudukan dan tugas pokoknya masing-masing.

Dalam sistem pemerintahan daerah menurut Undang-Undang Republik Indonesia Nomor 32 Tahun 2004 Tentang Pemerintahan Daerah, maka DPRD adalah sebagai unsur penyelenggaraan pemerintahan daerah. Istilah ini di kenal dengan istilah unsur penyelenggaraan pemerintahan daerah, kedudukan DPRD sejajar dan merupakan mitra kepala daerah, dengan fungsi masing-masing. DPRD lebih banyak menjalankan fungsi mengatur, mengawasi dalam bentuk membuat kebijakan berupa peraturan daerah, sedangkan kepala daerah lebih banyak menjalankan fungsi mengurus, dalam bentuk pelaksanaan kebijakan yang ditetapkan DPRD.

8 Rahyunir Rauf. Asas-Asas Penyelenggaraan Pemerintah Daerah. Yogyakarta: Nusamedia,. 2018. hlm. 313 
Hal yang perlu diperhatikan kemudian dalam konteks negara kesatuan penerapan asas sentralisasi dan desentralisasi dalam organisasi negara bangsa tidak bersifat dikotomi melainkan kontinum. Artinya pemerintah pusat tidak mungkin menyelenggarakan semua urusan pemerintahan ditangannya secara sentralisasi atau sebaliknya pemerintah daerah sepenuhnya menyelenggarakan semua urusan pemerintahan yang diserahkan. Yang bisa dilakukan adalah, selalu terdapat sejumlah urusan pemerintahan yang sepenuhnya diselenggarakan secara sentralisasi beserta penghalusannya, dekonsentrasi. Tidak pernah terdapat suatu urusan pemerintahan apa pun yang diselenggarakan sepenuhnya secara desentralisasi. Urusan pemerintah yang menyangkut kepentingan dan kelangsungan hidup berbangsa dan bernegara lazimnya diselenggarakan secara sentralisasi dan dekonsentrasi sedangkan urusan yang mengandung dan menyangkut kepentingan masyarakat setempat diselenggarakan secara desentralisasi ${ }^{9}$

Berdasarkan penjelasan di atas, maka dapat diketahui bahwa ke depannya guna menjalin hubungan yang lebih harmonis unsur kepala daerah dan unsur DPRD dalam proses penyelenggaraan pemerintahan daerah, dapat dilakukan dengan berbagai upaya, di antaranya, lembaga DPRD dengan badan legislasinya dan kepala daerah perlu duduk bersama untuk menetapkan agenda legislatif daerah, antara lain memuat rencana penyusunan rancangan peraturan daerah selama lima tahun. Termasuk pembagian tugas, proses penyusunannya bisa dengan menggunakan hak inisiatif dewan atau diajukan eksekutif daerah.

Sehingga kedudukan DPRD sebagai bagian dari fungsi pemerintahan daerah yang mempunyai andil besar dalam penataan pemerintahan daerah agar dalam masa rencana satuan kerja maupun rencana kerja lima tahun ke depan memiliki gambaran untuk peningkatan daerah atau wilayah yang memiliki pimpinan tertinggi pada wilayah tersebut. Undang-Undang Republik Indonesia Nomor 22 Tahun 1999, maka pada Undang-Undang Republik Indonesia Nomor 32 Tahun 2004 model pertanggungjawaban kepala daerah terlihat adanya perbedaan sangat mendasar dimana pada Undang-Undang Republik Indonesia Nomor 32 Tahun 2004 Tentang Pemerintahan Daerah tersebut kepala daerah bertanggungjawab kepada lembaga DPRD dan setiap tahun kepala daerah wajib

\footnotetext{
9 Sirajuddin dan Winardi, Hukum Tata Negara Indonesia, Malang: Setara Press (Kelompok Instras Publising), 2015, hlm 333. Lihat juga di Muhammad Junaidi, Reposisi Eksekutif Review Terhadap Peraturan Daerah dalam Kerangka Otonomi Daerah, Halu Oleo Law Review, Volume 1 Issue 1, March 2017 http://ojs.uho.ac.id/index.php/holrev/article/view/2350, diakses 11 April 2019, hlm. 64-74.
} 
menyampaikan semacam progress report laporan keterangan pertanggungjawaban kepala daerah kepada DPRD sebagai fungsi kontrol dan pengawasan, yang tidak bermuara kepada pemecatan, akan tetapi lebih kepada pemberian saran-saran dan masukan-masukan atau rekomendasi untuk perbaikan penyelenggaraan pemerintah daerah ke depan.

\section{KESIMPULAN}

Pada hakikatnya otonomi daerah diberikan kepada rakyat sebagai satu kesatuan masyarakat hukum yang diberikan kewenangan untuk mengatur dan mengurus sendiri pemerintahan yang diberikan oleh pemerintah pusat kepada daerah dan dalam pelaksanaannya dilakukan oleh Kepala Daerah dan Dewan Perwakilan Rakyat Daerah (DPRD) sebagai lembaga yang berfungsi sesuai kewenangan pengawasan dengan dibantu oleh perangkat daerah lainnya. Dalam negara kesatuan Republik Indonesia, demokrasi yang dimaksudkan itu adalah demokrasi Pancasila. Sebutannya mudah ketika diurai, mengandung semacam ajaran yang abstrak dan dari operasional. Bahkan operasionalisasinya senantiasa dinilai tidak terlepas dari kepentingan politik, khususnya oleh penguasa.

\section{Daftar Pustaka}

\section{Buku}

Halim, Abd. Politik Lokal, Aktor, Problem, dan Konflik Dalam Arus Demokratisasi. Malang Jatim, Intrans Publishing, 2018.

Karianga, Hendra. Politik Hukum Dalam Pengelolaan Keuangan Negara. Jakarta: Prenadamedia Group, 2013.

Rauf, Rahyunir. Asas-Asas Penyelenggaraan Pemerintah Daerah. Yogyakarta: Nusamedia, 2018.

Sirajuddin dan Winardi, Hukum Tata Negara Indonesia, Malang: Setara Press (Kelompok Instras Publising), 2015.

Wahidin, Samsul. Hukum Pemerintahan Daerah, "Mengawasi Pemilihan Umum Kepala Daerah". Yogyakarta: Pustaka Pelajar, 2008.

Zuhro, Siti dkk. Demokrasi Lokal Perubahan dan Kesinambungan. Yogyakarta: Ombak, 2009. 


\section{Perundang-undangan}

Undang-Undang Republik Indonesia Nomor 32 Tahun 2004 tentang Pemerintah daerah (Lembaran Negara Republik Indonesia Tahun 2004 Nomor 125, Tambahan Lembaran Negara Republik Indonesia Nomor 4437)

\section{e-jurnal}

Junaidi, Muhammad, Reposisi Eksekutif Review Terhadap Peraturan Daerah dalam Kerangka Otonomi Daerah, Halu Oleo Law Review, Volume 1 Issue 1, March 2017 http://ojs.uho.ac.id/index.php/holrev/article/view/2350, diakses 11 April 2019. 